\title{
Regulation of expression of ovarian mRNA encoding steroidogenic enzymes and gonadotrophin receptors by FSH and $\mathrm{GH}$ in hypogonadotrophic cattle
}

\author{
H. A. Garverick , G. Baxter ${ }^{2}$, J. Gong², D. G. Armstrong², \\ B. K. Campbell ${ }^{3}$, C. G. Gutierrez ${ }^{2}$ and R. Webb ${ }^{4}$ \\ ${ }^{1}$ Department of Animal Sciences, University of Missouri, Columbia, MO 65211, USA; \\ ${ }^{2}$ Division of Development and Reproduction, Roslin Institute (Edinburgh), Roslin, EH25 9PS, \\ UK; ${ }^{3}$ School of Human Development, University of Nottingham Queen's Medical Centre, \\ Nottingham NG7 2UH, UK; and ${ }^{4}$ School of Biosciences, University of Nottingham, Sutton \\ Bonington Campus, Loughborough LE12 5RD, UK
}

A study was conducted to determine the effects of FSH and bovine somatotrophin on the expression of mRNA encoding the gonadotrophin receptors and steroidogenic enzymes in ovarian follicles of cattle rendered hypogonadotrophic by treatment with a GnRH agonist. Hereford $\times$ Friesian heifers were allotted into two pretreatment groups: controls $(n=10)$ and $\mathrm{GnRH}$ agonisttreated $(n=20)$. Ovaries of control cows were removed on day 2 of the first follicular wave after synchronized oestrus. GnRH agonist-treated heifers were given either FSH or no FSH. FSH was infused at $50 \mu \mathrm{g} \mathrm{h}^{-1}$ for $48 \mathrm{~h}$. Ovaries in GnRH agonist-treated heifers were removed at the end of exogenous hormone treatment. The control, GnRH agonist and GnRH agonist plus FSH treatment groups were divided further into bovine somatotrophin or no bovine somatotrophin treatments ( $n=5$ per treatment). Bovine somatotrophin ( $25 \mathrm{mg} \mathrm{day}^{-1}$ by s.c. injection) was administered for 3 days. Ovaries were scanned once a day by ultrasonography. Blood samples for hormone measurements were collected three times a day from oestrus until the time of removal of ovaries. Expression of mRNAs for the $\mathrm{FSH}$ and $\mathrm{LH}$ receptors and cytochrome $\mathrm{P450}$ side-chain cleavage (P450scc), cytochrome P450 17 $\alpha$-hydroxylase (P450c17) and cytochrome P450 aromatase (P450arom) enzymes was localized by in situ hybridization and quantified by image analysis. Ovarian follicular growth was arrested at $\leq 4.5 \mathrm{~mm}$ in diameter in $\mathrm{GnRH}$ agonist-treated heifers. There was no effect of bovine somatotrophin on follicular dynamics, gonadotrophin secretion or expression of mRNA for either the gonadotrophin receptors or steroidogenic enzymes. Infusion of FSH to GnRH agonisttreated heifers increased FSH concentrations in serum to the physiological concentrations observed in controls and stimulated growth of follicles to a size similar $(5.5-8.0 \mathrm{~mm}$ in diameter) to recruited follicles in control cows. FSH induced mRNA expression of P450scc and P450arom in granulosa cells of follicles at a smaller size $(\leq 4.5 \mathrm{~mm}$ in diameter) than in controls and increased $(P<0.001)$ expression in larger $(>4.5 \mathrm{~mm}$ in diameter) follicles. Expression of mRNAs for P450scc and P450c17 increased $(P<0.001)$ with increasing follicle size and was higher $(P<0.01)$ in theca cells of GnRH agonist plus FSH-treated heifers than in the other groups. There were no treatment differences in expression of $\mathrm{FSH}$ receptor in granulosa cells or $\mathrm{LH}$ receptor in theca cells, but expression of both receptors increased with follicle size. There was no expression of LH receptor in the granulosa cells of cows from any treatment group. In conclusion, FSH treatment in $\mathrm{GnRH}$ agonisttreated heifers induced similar changes in follicular growth to those observed during the first follicular wave, but despite similar peak concentrations, prolonged exposure to high FSH induced precocious expression of mRNAs for P450scc and P450arom in granulosa cells from small follicles and markedly upregulated expression of these enzymes in granulosa cells from recruited follicles. The results of this study demonstrate the key role that $\mathrm{FSH}$ plays in the induction of follicular growth and differentiation.

\section{Introduction}

In cattle, follicular growth during the oestrous cycle is characterized by waves of follicular growth, whereby a cohort of follicles is recruited from small antral follicles for

Email: GarverickA@missouri.edu continued growth. One follicle is selected from this cohort and the selected follicle becomes dominant over the others, which undergo atresia (Adams et al., 1992; for a review, see Ginther et al., 1996). Recently, localization and quantification of mRNAs encoding the gonadotrophin receptors (FSH receptor and $\mathrm{LH}$ receptor) and key steroidogenic enzymes (cytochrome P450 side-chain cleavage (P450scc), 
cytochrome P450 17 $\alpha$-hydroxylase (P450c17) and cytochrome P450 aromatase (P450arom)) have been characterized (for reviews, see Bao and Garverick, 1998; Webb et al., 1999). Recruitment of follicles is associated with expression of mRNAs encoding P450scc and P450arom in granulosa cells, and selection of follicles is associated with expression of mRNAs encoding $\mathrm{LH}$ receptor and $3 \beta$-hydroxysteroid dehydrogenase (3ß-HSD) in granulosa cells (Xu et al., 1995a,b; Bao et al., 1997). In addition, an increase in mRNAs encoding P450scc, P450c17 and 3ß-HSD, but not P450arom, is associated with differentiation of preovulatory follicles during the follicular phase in cattle (Tian et al., 1995). Much of the previous work has focused on growth and differentiation of large follicles developing in a milieu of normal gonadotrophin secretion. Recently, a GnRH agonist model has been developed that inhibits gonadotrophin secretion and arrests growth of follicles at $\leqslant 4 \mathrm{~mm}$ in diameter (Gong et al., 1996). This model provides an excellent opportunity to study the factors controlling growth of smaller follicles and the hormone requirements for continued growth of these follicles.

The major endocrine regulators of follicular growth in cattle are the gonadotrophins, $\mathrm{FSH}$ and $\mathrm{LH}$, that bind to their cell surface receptors on the ovary. However, it is becoming increasingly apparent that locally produced factors (for example, inhibin, activin, insulin-like growth factors I (IGF-I) and II (IGF-II)), and extragonadal factors (somatotrophin, insulin and IGF-I) have a modulating effect on follicular growth (Webb et al., 1999). Exogenous bovine somatotrophin increases the number of small follicles in lactating cows (De la Sota et al., 1993) and in heifers (Gong et al., 1991). The mechanism or mechanisms by which bovine somatotrophin increases the development of bovine follicles and responsiveness to gonadotrophins has not been elucidated. The general aims of the present study were to determine the effects of FSH and bovine somatotrophin on the expression of mRNAs encoding the gonadotrophin receptors and key steroidogenic enzymes in bovine follicles using the $\mathrm{GnRH}$ agonist model. The specific aims were: (i) to determine whether the effect of bovine somatotrophin on increasing follicular populations was independent of gonadotrophin support; and (ii) to determine the effects of bovine somatotrophin and exogenous $\mathrm{FSH}$ on the expression of mRNAs encoding the FSH and $\mathrm{LH}$ receptors, and P450scc, P450c17 and P450arom enzymes.

\section{Materials and Methods}

\section{Animals and treatments}

The study was conducted in accordance with the Roslin Institute's Use of Experimental Animals in Research Code of Practice under the UK Home Office Animals (Scientific Procedures) Act, 1986 . Thirty Hereford $\times$ Friesian beef heifers ( $n=5$ per group) aged approximately 30 months were allotted into two pretreatment groups (Fig. 1): controls $(n=10)$ and $\mathrm{GnRH}$ agonist-treated $(n=22)$. Heifers in the pretreatment control group were divided further into two groups ( $n=5$ in each). In both control groups, oestrus was synchronized with progesterone intravaginal releasing devices (PRIDs; Sanofi Animal Health Ltd, Watford) implanted for 10 days and 25 mg PGF $2 \alpha$ (Lutalyse; Upjohn, Kalamazoo, MI) given on day 9 to induce luteal regression. Starting on the day after PRID removal, heifers were observed three times a day for oestrous behaviour. After the onset of oestrus, ovarian follicular growth was monitored once a day by real-time ultrasonography to determine changes in follicular development and to confirm inhibition of follicular development in $\mathrm{GnRH}$ agonist-treated heifers. Initiation of the first wave of follicles was identified by the growth of a cohort of follicles $>4.5 \mathrm{~mm}$ in diameter. Ovaries from both control groups were removed on the morning after initiation of the first wave of follicular growth (approximately 3 days after oestrus). The first group received no other treatments. In the second control group, heifers received s.c. injections of bovine somatotrophin (25 mg Somidobove; Elanco Animal Health, Basingstoke) once a day for 3 days beginning on the day of oestrus and the ovaries were then removed. Heifers in the $\mathrm{GnRH}$ agonist-treated group had Alzet osmotic minipumps $(2 \mathrm{ml}$; Charles River Ltd, Margate) implanted s.c. over the ribs behind the shoulders using normal surgical procedures and local anaesthetics. The pumps were loaded with $2 \mathrm{ml}$ GnRH agonist (1 $\mathrm{mg} \mathrm{ml}^{-1}$; Buserelin; Hoeschst Animal Health, Hounslow) to provide a constant release rate of $2.5 \mu \mathrm{h}^{-1}$ (Gong et al., 1996). The minipumps were removed after 28 days and a new minipump was implanted on the other side. Exogenous hormone treatments were initiated 17 days after insertion of the second minipump (approximately 7.5 weeks after initiation of $\mathrm{GnRH}$ agonist treatment). The GnRH agonist-treated heifers were divided into four groups $(n=5)$ as follows: group 3, untreated: ovaries were removed approximately 7.5 weeks after initiation of GnRH agonist treatment; group 4, bovine somatotrophin treatment: bovine somatotrophin $\left(25 \mathrm{mg} \mathrm{day}^{-1}\right.$ by s.c. injection) was given for 3 days and the ovaries were removed $24 \mathrm{~h}$ after the third bovine somatotrophin injection; group 5, FSH treatment: infusion of FSH $(50 \mu \mathrm{g}$ $\mathrm{h}^{-1}$; Ovagen; Immunoc-chemical Products Ltd, Auckland) was for $48 \mathrm{~h}$ and ovaries were removed after $48 \mathrm{~h}$ of infusion; group 6, FSH-bovine somatotrophin: bovine somatotrophin treatment was initiated $24 \mathrm{~h}$ before initiation of FSH treatment for 3 days and $\mathrm{FSH}$ was infused as described previously for $48 \mathrm{~h}$. Ovaries were removed after $48 \mathrm{~h}$ of FSH infusion. Time of removal of ovaries for groups 3-6 was similar after implantation of the first Alzet minipump (approximately 7.5 weeks).

\section{Tissue and blood collection, tissue preparation and hormone assays}

Ovaries were removed via a flank incision under aseptic conditions. Umbilical clamps were used to ligate the mesovarium (Youngquist et al., 1995). Procaine penicillin (30 ml; 

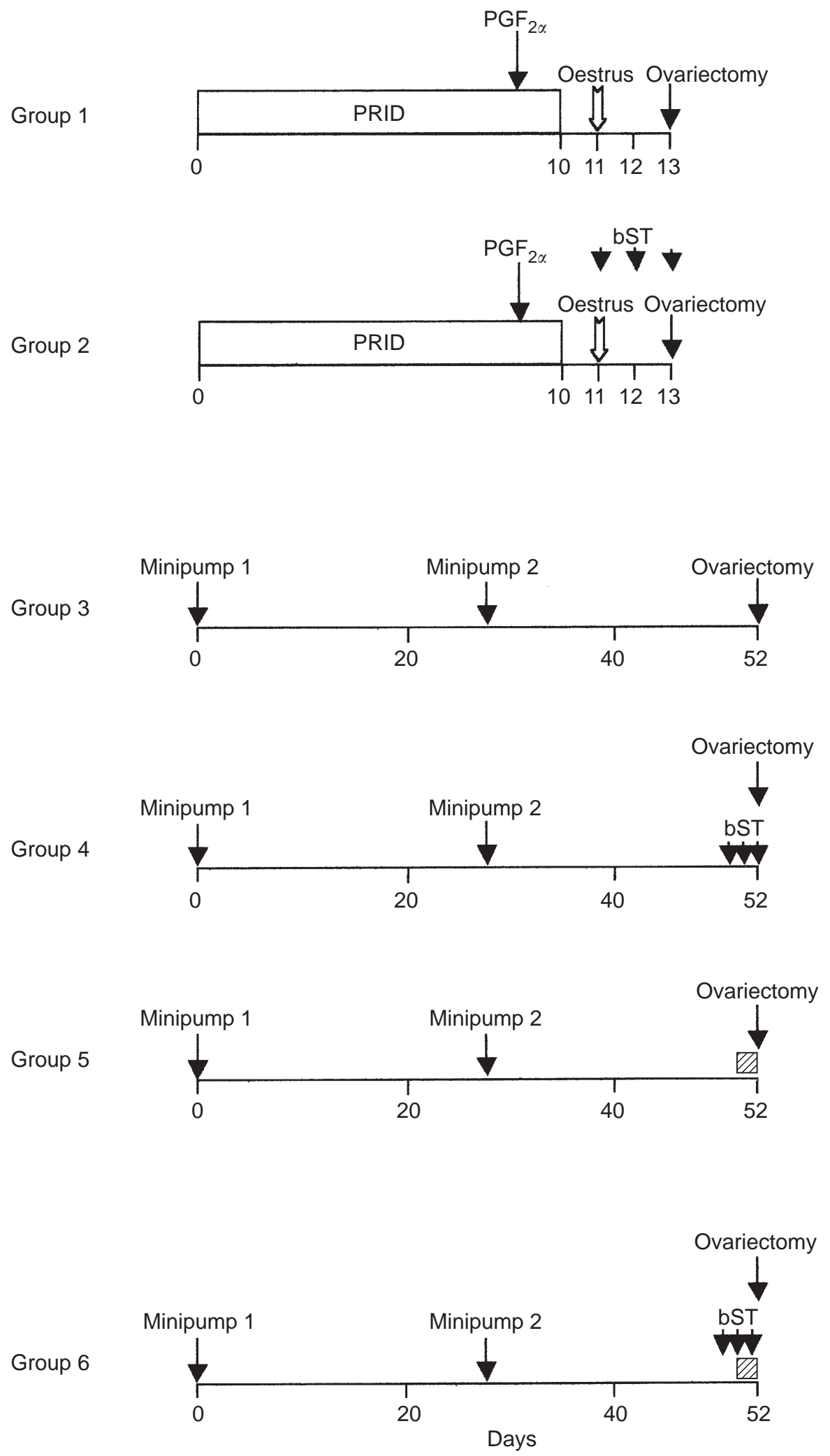

Fig. 1. Summary of experimental design. Minipumps 1 and 2 represent the times of insertion of the GnRH agonist minipumps. bST: bovine somatotrophin. The period of FSH infusion is represented by the hatched box $(\square)$. 
20000 iu $\mathrm{kg}^{-1}$ body weight) were injected s.c. once a day for 5 days after surgery. Blood samples $(10 \mathrm{ml})$ were collected three times a day from oestrus or initiation of treatment until surgery for measurement of gonadotrophin and steroid concentrations. Serum was collected after centrifugation at $1500 \mathrm{~g}$ at $4^{\circ} \mathrm{C}$ for $30 \mathrm{~min}$. Immediately after removal, both ovaries were placed on ice and transported to the laboratory. The ovaries were inspected and the numbers of surface follicles were counted and recorded. Blocks of tissue containing follicles were dissected from the ovaries, and the numbers and sizes of follicles $\geqslant 3 \mathrm{~mm}$ in diameter were recorded. The blocks of tissue were frozen over liquid nitrogen within 40 min of ovariectomy and stored at $-80^{\circ} \mathrm{C}$ until they were cut into sections. The size of each follicle was confirmed, wherever possible, after cutting into sections. Concentrations of FSH (Gong et al., 1996) and $\mathrm{LH}$ (Price et al., 1987) were measured by radioimmunoassay as described previously for our laboratory. The sensitivities of the $\mathrm{FSH}$ and $\mathrm{LH}$ assays were 0.11 and $0.12 \mathrm{ng} \mathrm{ml}^{-1}$, respectively. All samples were measured in a single assay for each hormone. Intra-assay coefficients of variation were $4.0 \%$ for $\mathrm{FSH}$ and $4.5 \%$ for $\mathrm{LH}$.

\section{In situ hybridization}

Generation of cDNAs for the $\mathrm{LH}$ and FSH receptors, and cytochrome P450scc, P450c17 and P450arom enzymes has been described previously (Xu et al., 1995a,b; Bao et al., 1997). Both antisense and sense [ ${ }^{35}$ S]UTP-labelled CRNA probes were transcribed from linearized cDNA templates using a transcription kit (Stratagene, LaJolla, CA) according to the manufacturer's recommendations. The cRNA probes were purified by centrifugation on a Sephadex G-50 column and used for hybridization within 2-3 days.

Procedures for in situ hybridization were as described previously (Xu et al., 1995a,b; Bao et al., 1997) with minor modifications. Sections (14 $\mu \mathrm{m}$ thickness) of follicular tissue were cut at $-22^{\circ} \mathrm{C}$ (specimen temperature) using a cryostat (Shandon Model OT, Runcorn) and mounted onto prechilled $\left(-32^{\circ} \mathrm{C}\right)$ microscope slides (Superfrost/Plus; Merck, Poole). Slides were air-dried and stored at $-80^{\circ} \mathrm{C}$ in desiccated, airtight boxes until fixation and hybridization. Before hybridization, the sections were fixed in $4 \%(\mathrm{v} / \mathrm{v})$ formaldehyde in $0.01 \mathrm{~mol} \mathrm{PBS} \mathrm{I-1}^{-1}$ for $5 \mathrm{~min}$, washed in $2 \times \mathrm{SSC}$ $(1 \times \mathrm{SSC}=0.3 \mathrm{~mol} \mathrm{NaCl} \mathrm{I}-1$ and $0.03 \mathrm{~mol}$ trisodium citrate $\left.\mathrm{I}^{-1}, \mathrm{pH} 7.0\right)$ for $2 \mathrm{~min}$, acetylated in $0.25 \%(\mathrm{v} / \mathrm{v})$ acetic anhydride in $0.1 \mathrm{~mol}$ triethanolamine $\mathrm{I}^{-1}(\mathrm{pH}$ 8.0) on an orbital shaker for $10 \mathrm{~min}$, rinsed in $2 \times \mathrm{SSC}$ for $2 \mathrm{~min}$ and dehydrated in increasing concentrations of ethanol $(60,80$, 95 and $100 \%(\mathrm{v} / \mathrm{v}))$ for $2 \mathrm{~min}$ each. The slides were incubated in chloroform for $5 \mathrm{~min}, 100 \%$ ethanol for $2 \mathrm{~min}$, 95\% ethanol for 2 min and air-dried.

For hybridization, the labelled probes were diluted in hybridization buffer $(40 \%(\mathrm{v} / \mathrm{v})$ formamide, $0.8 \times \mathrm{SSC}$, $1 \times$ Denhardt's solution $(0.02 \%(\mathrm{w} / \mathrm{v})$ ficoll, $0.02 \%(\mathrm{w} / \mathrm{v})$ polyvinylpyrrolidone and $0.02 \%(\mathrm{w} / \mathrm{v}) \mathrm{BSA}), 10 \mathrm{mmol}$ dithiothreitol $\mathrm{I}^{-1}, 500 \mu \mathrm{g}$ yeast tRNA ml $\mathrm{m}^{-1}$ and $10 \%(\mathrm{w} / \mathrm{v})$ dextran sulphate) to about $2 \times 10^{7}$ c.p.m. ml ${ }^{-1}$. Hybridization was performed using $50 \mu$ l diluted probe in humidified snap-sealed boxes under paraffin coverslips at $55^{\circ} \mathrm{C}$ for $20 \mathrm{~h}$. After hybridization, the slides were rinsed by dipping them several times in $2 \times \mathrm{SCC}\left(45-52^{\circ} \mathrm{C}\right)$, rinsed twice by shaking in $2 \times \mathrm{SSC}\left(45-52^{\circ} \mathrm{C}\right)$ for $15 \mathrm{~min}$ at room temperature and treated with Rnase $\mathrm{A}\left(50 \mu \mathrm{g} \mathrm{ml}^{-1}\right.$ in $\left.2 \times \mathrm{SSC}\right)$ for $1 \mathrm{~h}$ at $37^{\circ} \mathrm{C}$. The slides were washed at $55^{\circ} \mathrm{C}$ in $2 \times \mathrm{SSC}$ containing $0.1 \%(\mathrm{v} / \mathrm{v}) \beta$-mercaptoethanol (BME) for $15 \mathrm{~min}$, $1 \times$ SSC containing $0.1 \%(\mathrm{v} / \mathrm{v})$ BME for $15 \mathrm{~min}, 1 \times \mathrm{SSC}$ containing $50 \%(\mathrm{v} / \mathrm{v})$ formamide and $0.1 \%(\mathrm{v} / \mathrm{v})$ BME (SSC/MBE) for $30 \mathrm{~min}$, and twice in $0.1 \times \mathrm{SSC} / \mathrm{BME}$ for $15 \mathrm{~min}$. The slides were dehydrated, air-dried, dipped in Ilford $\mathrm{K} 2$ emulsion ( $\mathrm{H}$. A. West, Edinburgh) and exposed in the dark at $4^{\circ} \mathrm{C}$ for 14 days for receptors and 3 days for enzymes. The slides were developed, counterstained lightly with haematoxylin and eosin, and mounted for microscopic examination. For each follicle, two sections were hybridized with the antisense probe and one section was hybridized to the sense probe. Sections from animals ovariectomized on different days were balanced in each hybridization run to minimize biases as a result of variation among runs.

\section{Classification of follicles}

All measured follicles were classified morphologically as healthy, early atretic or atretic (Xu et al., 1995b). In brief, healthy follicles had a good complement of granulosa cells of which no more than a few were fragmented cells, a welldefined basement membrane and theca interna, with the thickness of the theca interna less than the thickness of the granulosa cells and the theca interna orientated parallel to the basement membrane. Early atretic follicles showed a few minor degenerative changes, such as the presence of a few pyknotic nuclei in the granulosa layer or local destruction of the basement membrane. Compared with early atretic follicles, atretic follicles were characterized by a greater destruction of follicular structure, a greater number of degenerative granulosa cells and a noticeable decrease or absence in the number of granulosa cells.

\section{Image analysis}

Hybridization intensity was quantified by image analysis performed on a Macintosh (Power PC Macintosh, Model $6100 / 60$ ) computer using the public domain NIH Image program (developed at the US National Institutes of Health and available from the Internet by anonymous FTP from zippy.nimh.nih.gov or on floppy disc from the National Technical Information Service, Springfield, VA, part number PB95-500195GEI). For each follicle, two fields were measured for both sections hybridized to the antisense probe and for the section hybridized to the sense probe $\mathrm{Xu}$ et al., 1995a). Specific hybridization intensity (the percentage of pixels containing a silver grain within a defined field) was defined as the average hybridization intensity for the two sections hybridized to the antisense probe minus the 
average hybridization intensity for the section hybridized to the sense probe.

\section{Statistical analysis}

Only follicles judged to be healthy were used in analyses. Follicles were divided into three size groups. The first size group was follicles $<1 \mathrm{~mm}$ in diameter. The second size group was follicles $1.0-4.5 \mathrm{~mm}$ in diameter (non-recruited). The third size group was follicles $>4.5 \mathrm{~mm}$ in diameter (recruited; see Webb et al., 1999). The sizes chosen were based on previous work showing that follicles that are recruited grow to $\geqslant 5 \mathrm{~mm}$ in diameter from smaller sizes (Adams et al., 1992) and that the GnRH agonist treatment decreased gonadotrophin secretion and restricted follicle size to about $\leqslant 4 \mathrm{~mm}$ in diameter (Gong et al., 1996). Follicles were measured in $0.5 \mathrm{~mm}$ increments. Data for mRNA expression of gonadotrophin receptors and steroidogenic enzymes were first analysed by ANOVA in a two (bovine somatotrophin versus no bovine somatotrophin) $\times$ three (control versus $\mathrm{GnRH}$ agonist versus GnRH agonist plus FSH) $\times$ three (follicle size) factorial analysis. It was found that bovine somatotrophin treatment did not affect mRNA expression for the gonadotrophin receptors or steroidogenic enzymes in the treatment period of this experiment and there was no effect of bovine somatotrophin on serum gonadotrophin concentrations. Therefore, a second ANOVA was performed, eliminating bovine somatotrophin from the model. The final analysis was conducted comparing treatment (control, GnRH agonist and $\mathrm{GnRH}$ agonist plus $\mathrm{FSH}$ ) and follicle size. All mRNA expression results presented are from the second analysis. Mixed model procedures were used to analyse serum gonadotrophin concentrations (SAS, 1999). Effects of the model included treatments, time, treatment $\times$ time interaction and individual identity. Values are mean \pm SEM.

\section{Results}

\section{Follicular dynamics}

There was no difference in total numbers of surface follicles among control $(38.4 \pm 6.0)$, GnRH agonist-treated $(42.9 \pm 6.4)$ and $\mathrm{GnRH}$ agonist plus FSH-treated $(43.4 \pm 5.4)$ heifers. The GnRH agonist treatment restricted follicular growth in 20 of 22 heifers. Only those heifers $(n=20)$ in which GnRH agonist treatment inhibited growth were used in $\mathrm{GnRH}$ agonist and $\mathrm{GnRH}$ agonist plus FSH treatment groups. In this respect, follicular growth in the $\mathrm{GnRH}$ agonist-treated heifers was restricted to $\leqslant 4.5 \mathrm{~mm}$ in diameter, except for a few follicles that were $>4.5 \mathrm{~mm}$ in diameter; none were $>5.5 \mathrm{~mm}$ in diameter. In control heifers (non-GnRH agonist-treated), the cohort of follicles of the first follicular wave (removed on day 2 after detection of the follicular wave) had grown to between $5.5 \mathrm{~mm}$ and $8.0 \mathrm{~mm}$ in diameter. In $\mathrm{GnRH}$ agonist-treated heifers given exogenous $\mathrm{FSH}$, recruited follicles grew to a size similar $(5.5-8.0 \mathrm{~mm})$ to recruited follicles in control heifers.
However, in GnRH agonist plus FSH-treated heifers, there were more $(P<0.001)$ recruited follicles $(>4.5 \mathrm{~mm}$ in diameter; $n=100 ; 10.0 \pm 1.3$ per heifer) than in the control group ( $n=57 ; 5.7 \pm 1.3$ per heifer). Treatment with bovine somatotrophin did not significantly affect either the size or number of follicles (data not shown).

\section{Serum gonadotrophins}

There was a treatment $(P<0.01)$ but not a time effect, and the treatment $\times$ time interaction was significant $(P<0.001)$ for serum concentrations of FSH. Serum concentration of $\mathrm{FSH}$ in the control group $(1.47 \pm 0.14 \mathrm{ng}$ $\mathrm{ml}^{-1}$ ) from oestrus to day 1 was higher than for $\mathrm{GnRH}$ agonist $\left(0.89 \pm 0.12 \mathrm{ng} \mathrm{ml}^{-1}\right)$ and $\mathrm{GnRH}$ agonist plus FSH $\left(0.73 \pm 0.11 \mathrm{ng} \mathrm{ml}^{-1}\right)$ groups. Serum concentration of FSH decreased $(P<0.05)$ with recruitment of follicles after oestrus in controls $\left(0.77 \pm 0.13 \mathrm{ng} \mathrm{ml}^{-1}\right)$. In contrast, serum concentrations of $\mathrm{FSH}$ in $\mathrm{GnRH}$ agonist-treated heifers remained at basal concentrations throughout the experimental period. In $\mathrm{GnRH}$ agonist-treated heifers given $\mathrm{FSH}$, serum concentrations of $\mathrm{FSH}$ increased after $\mathrm{FSH}$ infusion to concentrations $\left(1.57 \pm 0.11 \mathrm{ng} \mathrm{ml}^{-1}\right)$ similar to those observed in controls at oestrus and before recruitment.

There was a treatment, time and treatment $\times$ time interaction (all $P<0.001$ ) for serum concentrations of $\mathrm{LH}$. Mean concentration of $\mathrm{LH}$ was higher in controls at oestrus $\left(5.75 \pm 0.42 \mathrm{ng} \mathrm{ml}^{-1}\right)$ and on the day after oestrus $\left(2.31 \pm 0.35 \mathrm{ng} \mathrm{ml}^{-1}\right)$ in controls compared with both of the $\mathrm{GnRH}$ agonist groups during any time of the sampling period. Mean concentrations of $\mathrm{LH}$ in the $\mathrm{GnRH}$ agonist $\left(0.40 \pm 0.11 \mathrm{ng} \mathrm{ml}^{-1}\right)$ and $\mathrm{GnRH}$ agonist plus $\mathrm{FSH}$ $\left(0.44 \pm 0.10 \mathrm{ng} \mathrm{m}^{-1}\right)$ groups were at basal values throughout the experimental period. There were no changes in basal concentrations of $\mathrm{LH}$ in $\mathrm{GnRH}$ agonist-treated heifers in this study indicative of pulsatile secretion. Increased $\mathrm{LH}$ values, indicative of pulsatile secretion, as well as evidence of the preovulatory surge of $\mathrm{LH}$, were observed in some of the control heifers.

\section{Expression of mRNAs for steroidogenic enzymes}

P450scc. P450scc mRNA was expressed in both granulosa and theca cells. In granulosa cells, there was an effect $(P<0.001)$ of treatment and follicle size on mRNA expression and the treatment $\times$ size interaction was significant $(P<0.001$; Figs 2 and 3$)$. In controls, mRNA for P450scc was not expressed in granulosa cells of follicles $\leqslant 4.5 \mathrm{~mm}$ in diameter (non-recruited), but was expressed in the recruited cohort of follicles $>4.5 \mathrm{~mm}$ in diameter. In $\mathrm{GnRH}$ agonist-treated heifers, there was no mRNA expression for P450scc in granulosa cells except for low expression in a few follicles. In $\mathrm{GnRH}$ agonist plus FSH-treated heifers, mRNA expression for P450scc was induced by FSH treatment, which was higher $(P<0.01)$ in recruited follicles $>4.5 \mathrm{~mm}$ in diameter than for all of the other treatments and classes. In addition, P450scc mRNA expression was 

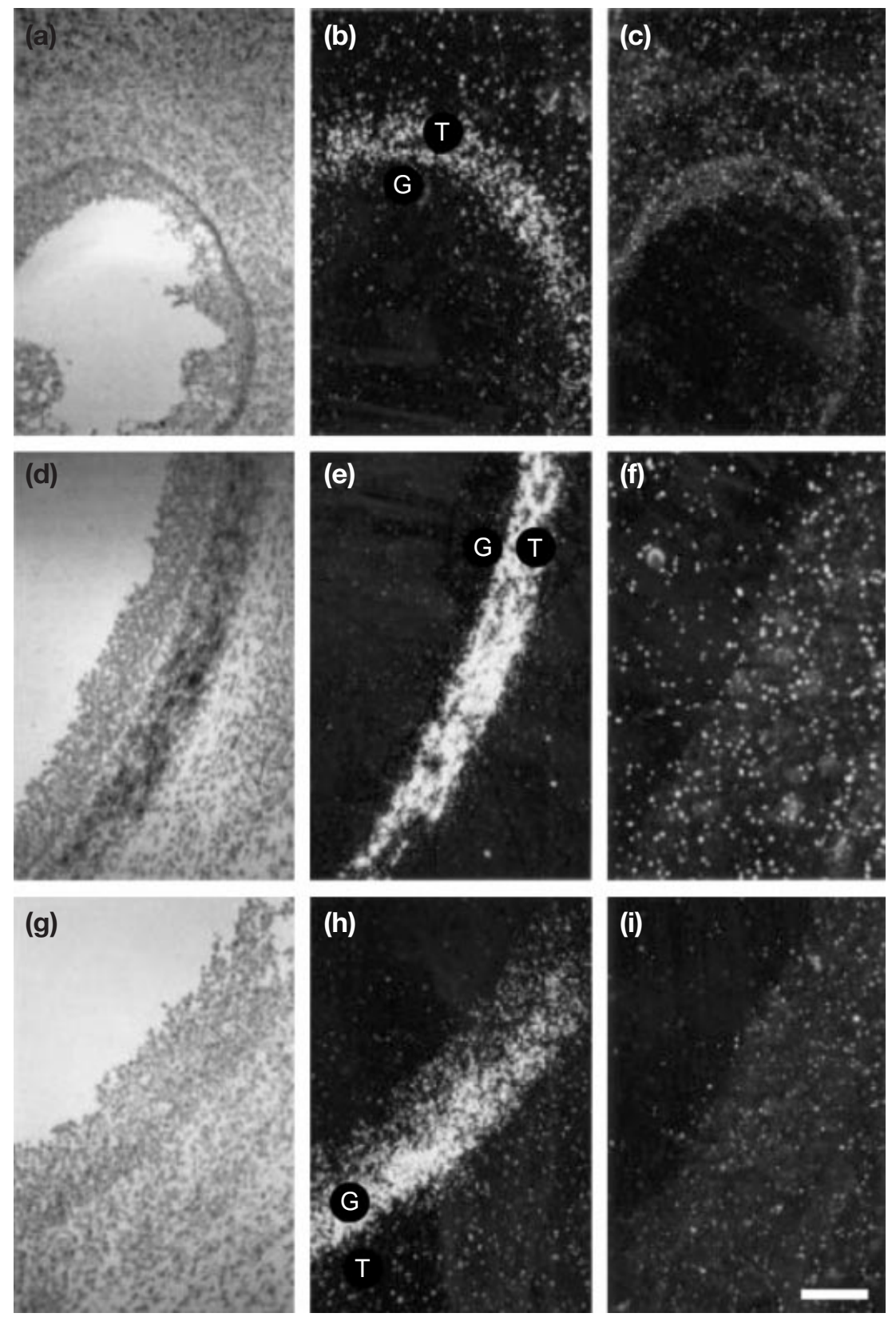

Fig. 2. (a,d,g) Bright field and (b,c,e,f,h,i) dark field images of a (a) $0.5 \mathrm{~mm}$ and (d,g) $4.5 \mathrm{~mm}$ in diameter bovine follicle probed with either (b) antisense or (c) sense ${ }^{35} \mathrm{~S}$ ]-labelled cytochrome P450 side-chain cleavage (P450scc) RNA or (e) antisense and ( $\mathrm{f}$ ) sense $\left[{ }^{35} \mathrm{~S}\right]$-labelled cytochrome P450 17 $\alpha$-hydoxylase (P450c17) RNA or (h) antisense and (i) sense $\left[{ }^{35} \mathrm{~S}\right.$ ]-labelled cytochrome P450 aromatase (P450arom) RNA. G: granulosa cell; T: theca cell. Scale bar represents $100 \mu \mathrm{m}$.

observed in follicles 1.0-4.5 mm in diameter in GnRH agonist plus FSH-treated animals that was similar in magnitude to that observed in recruited follicles $(5.5-8.0 \mathrm{~mm}$ in diameter) of control cows.

Expression of mRNA for P450scc in theca cells became higher $(P<0.001)$ with increasing follicular size and there was a tendency for expression to be affected by treatment, although this was not significant (Figs 2 and 4). The treat- ment $\times$ size interaction was not significant. In GnRH agonist plus FSH-treated heifers, mRNA expression was higher $(P<0.05)$ in recruited follicles than in other follicles. Expression (\% pixels) of mRNA for P450scc in granulosa cells was $11.7 \pm 3.7$ and $11.2 \pm 3.9$, and in theca cells was $37.5 \pm 8.6$ and $35.6 \pm 8.7$, for non-bovine somatotrophinand bovine somatotrophin-treated heifers, respectively (not significant). 


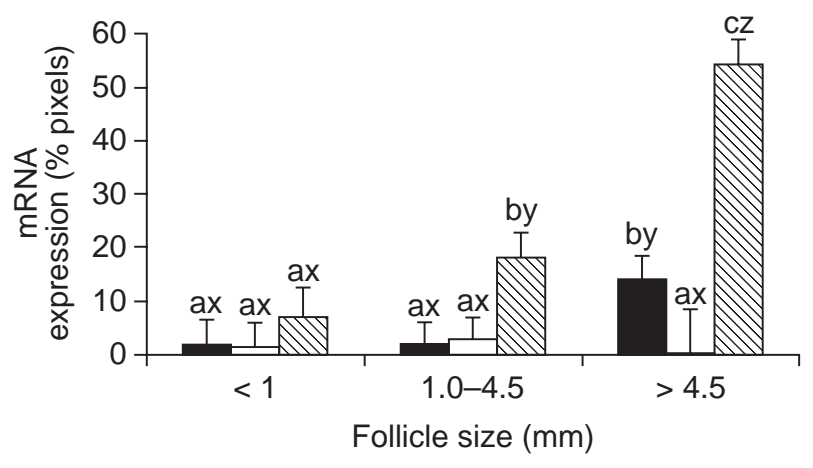

Fig. 3. Expression of cytochrome P450 side-chain cleavage (P450scc) mRNAs (mean \pm SEM) in granulosa cells in bovine follicles collected on day 2 of the first follicular wave (control; and after GnRH agonist treatment without (GnRH agonist; $\square$ ) and with ( $\mathrm{GnRH}$ agonist plus $\mathrm{FSH} ; \mathbb{\nabla}$ ) FSH treatment. The intensity of hybridization is quantified as the percentage of pixels within the given marked area occupied by silver grains. ${ }^{a-c}$ Different letters indicate differences among treatments within days $(P<0.05)$. ${ }^{x-z}$ Different letters indicate differences between days within treatment group $(P<0.05)$.

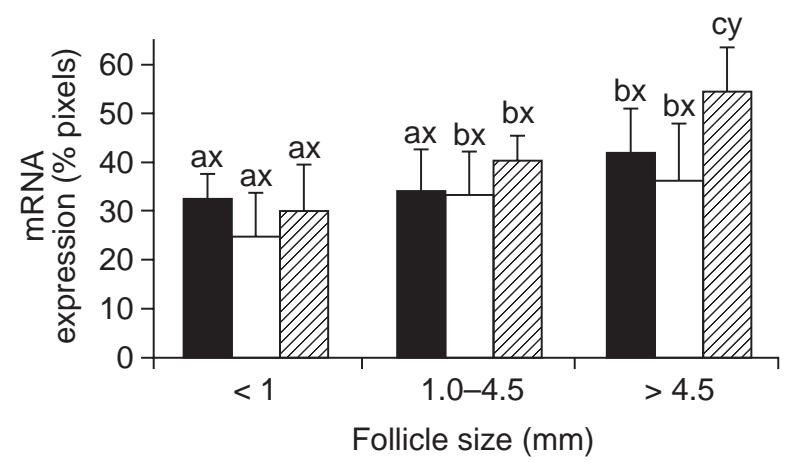

Fig. 4. Expression of cytochrome P450 side-chain cleavage (P450scc) mRNAs (mean \pm SEM) in theca cells in bovine follicles collected on day 2 of the first follicular wave (control; $\square$ ) and after $\mathrm{GnRH}$ agonist treatment without (GnRH agonist; $\square)$ and with $(\mathrm{GnRH}$ agonist plus $\mathrm{FSH} ; \square) \mathrm{FSH}$ treatment. The intensity of hybridization is quantified as the percentage of pixels within the given marked area occupied by silver grains. ${ }^{a-c}$ Different letters indicate differences among treatments within days $(P<0.05)$. ${ }^{x-z}$ Different letters indicate differences between days within treatment group $(P<0.05)$.

P450c17. mRNA expression of P450c17 was localized to theca cells only. Expression of P450c17 mRNA varied $(P<0.01)$ with treatment and size of follicle (Figs 2 and 5 ). Expression of P450c17 mRNA increased $(P<0.001)$ with follicle size and the $\mathrm{GnRH}$ agonist plus $\mathrm{FSH}$-treated group had a higher $(P<0.01)$ mRNA expression than controls or $\mathrm{GnRH}$ agonist only-treated heifers. The treatment $\times$ size of follicle interaction was not significant. Expression (\% pixels) of mRNA for P450c17 was $42.8 \pm 4.1$ and $45.9 \pm 4.4$ for non-bovine somatotrophin- and bovine somatotrophintreated heifers, respectively (not significant).

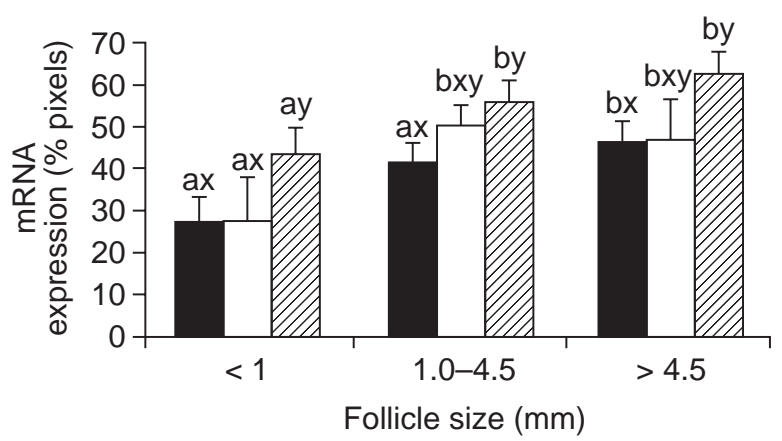

Fig. 5. Expression of cytochrome P450 17 $\alpha$-hydroxylase (P450c17) mRNAs (mean \pm SEM) in theca cells in bovine follicles collected on day 2 of the first follicular wave (control; $\mathbf{0}$ ) and after $\mathrm{GnRH}$ agonist treatment without $(\mathrm{GnRH}$ agonist; $\square)$ and with $(\mathrm{GnRH}$ agonist plus $\mathrm{FSH} ; 叉) \mathrm{FSH}$ treatment. The intensity of hybridization is quantified as the percentage of pixels within the given marked area occupied by silver grains. ${ }^{a-c}$ Different letters indicate differences among treatments within days $(P<0.05) .{ }^{x-z}$ Different letters indicate differences between days within treatment group $(P<0.05)$.

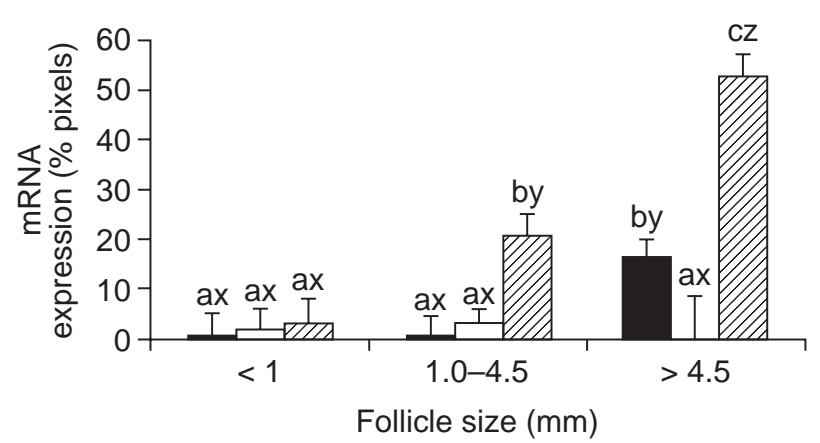

Fig. 6. Expression of cytochrome P450 aromatase (P450arom) mRNAs (mean \pm SEM) in granulosa cells in bovine follicles collected on day 2 of the first follicular wave without (control; $\mathbf{\square}$ ) and after GnRH agonist treatment without (GnRH agonist; $\square$ ) and with (GnRH agonist plus FSH; $\$ ) FSH treatment. The intensity of hybridization is quantified as the percentage of pixels within the given marked area occupied by silver grains. ${ }^{a-c}$ Different letters indicate differences among treatments within days $(P<0.05)$. ${ }^{x-z}$ Different letters indicate differences between days within treatment group $(P<0.05)$.

P450arom. Expression of mRNA for P450arom was localized to granulosa cells only. There was a treatment and size difference $(P<0.001)$ in mRNA expression of P450arom, and the treatment $\times$ size interaction was significant $(P<0.001$; Figs 2 and 6$)$. There was no expression of P450arom mRNA in the two smallest sizes of follicles $(\leqslant 4.5 \mathrm{~mm})$ in controls. Expression of mRNA for P450arom was observed only in recruited follicles of $>4.5 \mathrm{~mm}$ in diameter in controls. P450arom mRNA was not detected in follicles of the GnRH agonist-treated heifers except for low expression in a few follicles. In contrast, expression of 

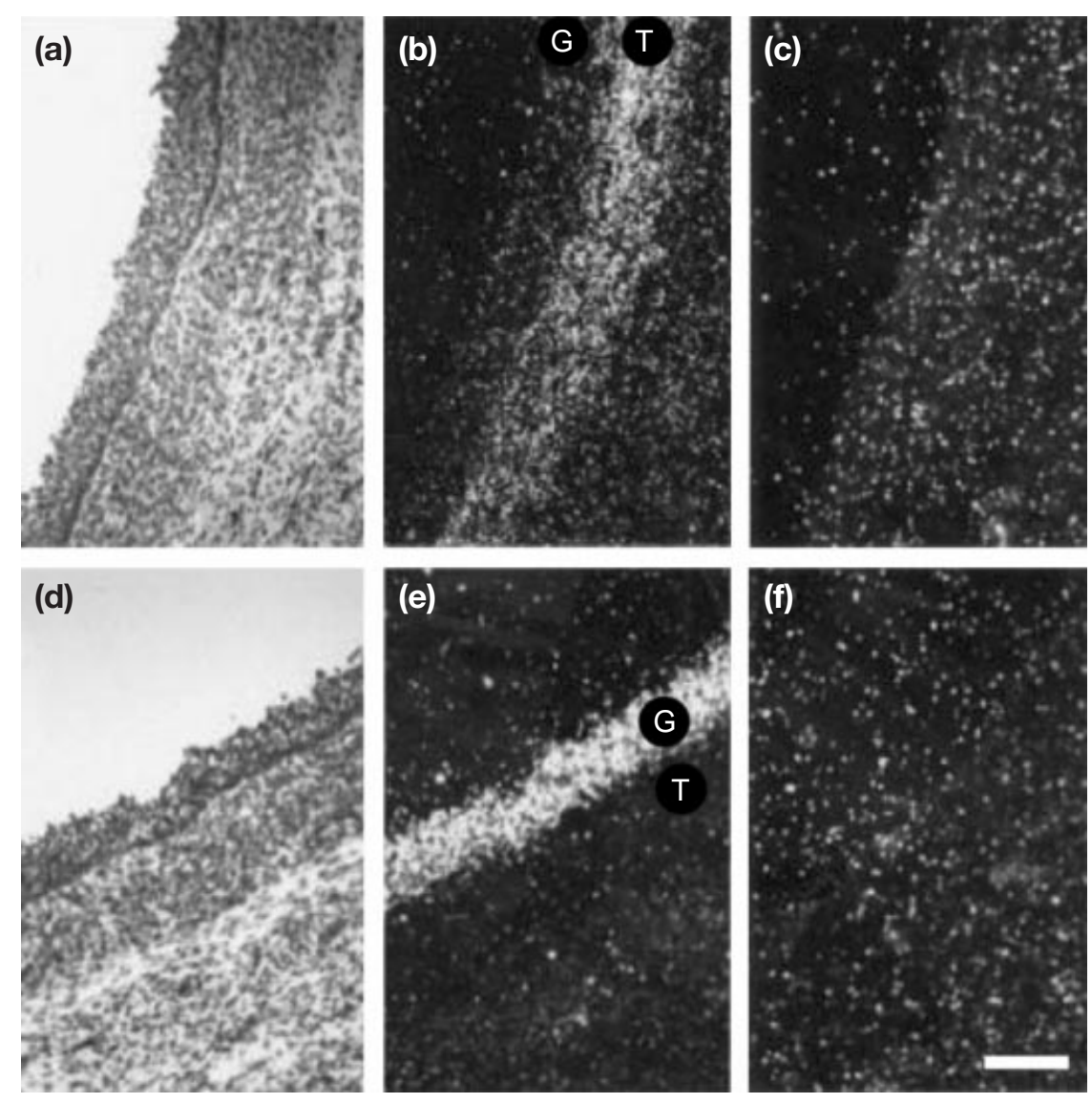

Fig. 7. (a,d) Bright field and (b,c,e,f) dark field images of a $4.5 \mathrm{~mm}$ diameter bovine follicle probed with either (b) antisense and (c) sense $\left.{ }^{35} \mathrm{~S}\right]$-labelled LH receptor RNA or (e) antisense and ( $\mathrm{f}$ ) sense $\left[{ }^{35} \mathrm{~S}\right]$-labelled FSH receptor RNA. G: granulosa cell; T: theca cell. Scale bar represents $100 \mu \mathrm{m}$.

mRNA for P450arom was detected in some follicles 1.0-4.5 mm in diameter in GnRH agonist plus FSH-treated heifers at a level similar to recruited follicles in controls (Fig. 6). Expression of mRNA for P450arom was higher $(P<0.001)$ in follicles $>4.5$ in diameter (recruited) in GnRH agonist plus FSH-treated heifers than in all other treatments and in all other follicle sizes. Expression (\% pixels) of mRNA for P450arom was $13.3 \pm 2.3$ and $9.4 \pm 2.8$ for non-bovine somatotrophin- and bovine somatotrophintreated heifers, respectively (not significant).

\section{Expression of $m R N A$ s for gonadotrophin receptors}

$\mathrm{FSH}$ receptor. Expression of $\mathrm{mRNA}$ for the $\mathrm{FSH}$ receptor was localized to granulosa cells and increased $(P<0.01)$ with increasing follicle diameter (Fig. 7). Hybridization intensity (\% pixels) for the $\mathrm{FSH}$ receptor was $11.7 \pm 2.0$, $14.4 \pm 1.7$ and $18.7 \pm 2.4$ for follicles $<1.0,1.0-4.5$ and $>4.5 \mathrm{~mm}$ in diameter, respectively. There were no differences among treatments, and the treatment $\times$ size of follicle interaction was not significant. Expression of mRNA for FSH receptor was $14.7 \pm 2.0$ and $15.1 \pm 2.1$ for non-bovine somatotrophin- and bovine somatotrophin-treated heifers, respectively (not significant).

$\mathrm{LH}$ receptor. There was no expression of $\mathrm{LH}$ receptor in granulosa cells of follicles of any size or treatment (Fig. 7). Expression of $\mathrm{LH}$ receptor $\mathrm{mRNA}$ in theca cells increased $(P<0.001)$ with follicular size but was not influenced by treatment, and the treatment $\times$ size of follicle interaction was not significant. Hybridization intensity (\% pixels) for the $\mathrm{LH}$ receptor was $11.9 \pm 2.3,19.0 \pm 2.0$ and $21.8 \pm 2.9$ for follicles <1.0, 1.0-4.5 and $>4.5 \mathrm{~mm}$ in diameter, respectively. Expression of mRNA for the $\mathrm{LH}$ receptor in theca cells was $17.0 \pm 2.3$ and $17.7 \pm 2.5$ for non-bovine somatotrophin- and bovine somatotrophin-treated heifers, respectively (not significant).

\section{Discussion}

The results of the present study highlight the importance of dose and duration of exposure to $\mathrm{FSH}$ in the induction of follicular growth and differentiation, and establish that the 
GnRH agonist-suppressed gonadotrophin-treated heifer is a potentially useful model to study the mechanisms controlling follicular recruitment, selection and dominance in monovular species. Inhibition of gonadotrophin secretion in the present study with the GnRH agonist model (Gong et al., 1996) resulted in arrest of ovarian follicular growth at $\leqslant 4.5 \mathrm{~mm}$ in diameter, which is associated with nonrecruited follicles in heifers. Expression of mRNAs encoding the gonadotrophin receptors and P450scc, P450c17 and P450arom in non-recruited follicles of the $\mathrm{GnRH}$ agonisttreated heifers was similar to expression observed in nonrecruited follicles in heifers with normal oestrous cycles in previous studies (Xu et al., 1995a,b; Bao et al., 1997).

The amount of $\mathrm{FSH}$ infused in the present study increased circulating concentrations of FSH to values similar to those observed during the peak of the transient increase of $\mathrm{FSH}$ in control heifers and similar to concentrations associated with follicular recruitment (Adams et al., 1992; Hamilton et al., 1993). Within $48 \mathrm{~h}$, infusion of $\mathrm{FSH}$ into $\mathrm{GnRH}$ agonisttreated heifers in the present study stimulated follicles to grow to a size similar to recruited follicles in controls. FSH also induced significant expression of mRNAs for both the P450scc and P450arom enzymes. Thus, in the current model of suppressed endogenous gonadotrophins, FSH infusion in the physiological range appears to be the stimulus to initiate expression of mRNA for P450scc and P450arom in granulosa cells. This finding is comparable to normal oestrous cycles, in which temporal changes in follicular recruitment are observed only after a transient increase in FSH (Adams et al., 1992; Hamilton et al., 1993), and expression of mRNAs for P450scc and P450arom in granulosa cells is first observed in recruited follicles ( $\mathrm{Xu}$ et al., 1995a, Bao et al., 1997). Further evidence of the role of $\mathrm{FSH}$ in controlling follicular growth is the finding from the present study that expression of the mRNAs for P450scc and P450arom is increased in recruited follicles in the $\mathrm{GnRH}$ agonist plus FSH-treated group compared with the control group and that mRNA expression for P450scc and P450arom was induced in granulosa cells from smaller follicles compared with the control group. Similarly, expression of P450c17 mRNA in recruited follicles after FSH infusion in $\mathrm{GnRH}$ agonist-treated heifers was higher compared with controls. Thus, infusion of FSH into hypogonadotrophic heifers stimulated follicular growth and intra-follicular changes in gene expression that have been associated with follicular recruitment and maturation in cattle (see Webb et al., 1999).

Although the amount of FSH infused is in the physiological range, similar to that observed during the transient increase in $\mathrm{FSH}$ that initiates emergence of a follicular wave, infusion of FSH in the current study remained at a constant level. This is in contrast to the decrease in $\mathrm{FSH}$ secretion observed at about the time that emergence of a follicular wave is detected (Adams et al., 1992; Hamilton et al., 1993). Thus, infusion of FSH for $48 \mathrm{~h}$ in the present study probably provided follicles with a slightly higher amount of $\mathrm{FSH}$ than would be normal. Infusion of $\mathrm{FSH}$ initiated expression of mRNAs for P450scc and P450arom in smaller-sized follicles (follicles $<4.5 \mathrm{~mm}$ in diameter) than previously observed (recruited follicles $>5 \mathrm{~mm}$ in diameter; Xu et al., 1995a; Bao et al., 1997). This observation provides further evidence for the role of $\mathrm{FSH}$ in inducing the capability of follicles to produce oestradiol. In previous studies (Xu et al., 1995a; Bao et al., 1997), it was observed that some follicles in a cohort, which were $5 \mathrm{~mm}$ in diameter early in recruitment, did not express mRNA for P450scc and P450arom. Later in recruitment, follicles that continued to grow to $6-8 \mathrm{~mm}$ in diameter all expressed mRNA for P450scc and P450arom. Follicles that remained just $>5 \mathrm{~mm}$ in diameter were those that did not express mRNAs for P450scc and P450arom. Thus, continued growth of recruited follicles to the selection stage is probably dependent on their ability to secrete oestradiol. A further observation from the present study is that expression of P450scc and P450c17 mRNAs in theca cells of follicles $>4.5 \mathrm{~mm}$ in diameter was higher in follicles in GnRH agonisttreated heifers given exogenous $\mathrm{FSH}$ than in recruited follicles in the control group. Although not proven definitively in the present study, it is possible that the increased expression of the enzymes necessary for androgen production may be a result of increased conversion of androgens to oestradiol in the FSH-infused heifers. Alternatively, as FSH induced maturational changes in granulosa cells, FSH may produce a stimulatory effect through a paracrine mechanism (Smythe et al., 1993). Inhibin A is one such candidate for this factor, as it upregulates LH-simulated androgen production by theca cells in sheep (Campbell and Baird, 2001). Another mechanism is through FSH-induced changes in the follicular IGF system (Armstrong and Webb, 1997; Armstrong et al., 1998). Changes in IGF binding protein (IGFBP) mRNA expression can control IGF bioavailability in follicles, which, in turn, can regulate the sensitivity of granulosa cells to $\mathrm{FSH}$.

Expression of mRNAs for the gonadotrophin receptors was not affected in the smaller follicles of GnRH agonisttreated heifers when compared with follicles of similar size exposed to normal concentrations of gonadotrophins. Thus, mRNA expression for the gonadotrophin receptors, at least in smaller follicles (before recruitment), may be constitutive. $\mathrm{FSH}$ receptor mRNA has been detected in follicles with only one or two layers of granulosa cells (Xu et al., 1995a). However, expression of mRNAs for P450scc and P450arom is not detected in granulosa cells until follicles are $>5 \mathrm{~mm}$ in diameter after stimulation from a transient increase in circulating FSH. This is about the stage that follicles first secrete significant quantities of oestradiol (Skyer et al., 1987). In the present study, infusion of FSH at a constant rate in GnRH agonist-treated heifers induced mRNA expression of P450scc and P450arom at a smaller size than detected in controls, thereby further demonstrating the role of FSH in induction of mRNAs encoding P450scc and P450arom. In a previous report, infusion of $\mathrm{FSH}$ into sheep treated with follicular fluid that had been steroid-depleted with dextran-coated charcoal increased P450arom activity 
in cultured granulosa cells, and P450arom activity was increased with increased FSH treatment (McNatty et al., 1985). Although follicular growth can proceed to 2-4 mm in diameter in cattle (present study; Gong et al., 1996) and to 1-2 $\mathrm{mm}$ in sheep (McNeilly et al., 1991) in the absence of pulsatile $\mathrm{LH}$ release and significantly decreased $\mathrm{FSH}$ concentration, FSH may stimulate the growth of preantral follicles both in vitro (Gutierrez et al., 2000) and in vivo (Campbell et al., 2000).

Expression of $\mathrm{mRNA}$ for $\mathrm{LH}$ receptor, as well as mRNAs for steroidogenic enzymes, necessary for androgen biosynthesis (P450scc, P450c17 and 3 $\beta$-HSD), is detected soon after the formation of thecal cell layers (Xu et al., 1995a; Bao et al., 1997). This is about the time that follicles gain the capability to express mRNA encoding IGF-II (Armstrong et al., 2000). Thus, the capability of follicles to secrete androgens appears to occur at about the time of antrum formation and may be regulated by intrafollicular IGF-II production. In addition, the results of the present study demonstrate clearly that expression of $\mathrm{LH}$ receptor and $\mathrm{FSH}$ receptor mRNAs in all of the experimental groups is similar to that observed in previous studies (Xu et al., 1995a,b; Bao et al., 1997), thus confirming the association of increasing mRNA expression of $\mathrm{FSH}$ receptor in granulosa cells and $\mathrm{LH}$ receptor in theca cells with increasing follicular size. Expression of $\mathrm{LH}$ receptor mRNA was not detected in granulosa cells of any follicles in the present study. This was expected, as follicles did not grow to $>8 \mathrm{~mm}$ in diameter. Expression of $\mathrm{LH}$ receptor in granulosa cells has been associated with selection of dominant follicles $>9 \mathrm{~mm}$ in diameter $(\mathrm{Xu}$ et al., 1995a; Bao et al., 1997). Similarly, binding of LH to granulosa cells occurs in selected and dominant follicles only (Ireland and Roche, 1982; Webb and England, 1982).

It was anticipated that treatment with bovine somatotrophin would increase the number of small follicles (Gong et al., 1991); however, no such increase was observed. The lack of an increase in the number of small follicles may have been a result of the short period (3 days) of bovine somatotrophin treatment before removal of ovaries, as it takes at least 3 days before an increase in number of follicles can be detected after bovine somatotrophin treatment (Gong et al., 1991). A previous bovine somatotrophin dose-response study demonstrated that the increase in the number of small follicles appears to be mediated through an increase in circulating IGF-I or insulin concentrations, rather than via an alteration in the secretion of pituitary gonadotrophins or a direct effect of bovine somatotrophin on ovarian follicles (Gong et al., 1997). Importantly, the aim of the present study was to investigate the interaction between FSH and bovine somatotrophin on patterns of gene expression of steroid enzymes and gonadotrophin receptors, an action that would probably occur well before any changes in follicular gross morphology could be detected.

In conclusion, the results from the present study provide new insights into the mechanism of follicular recruitment in cattle and into key intra-follicular maturational changes associated with follicular recruitment. FSH increased follicular growth in GnRH agonist-treated heifers (recruitment) and induced expression of mRNAs encoding P450scc and P450arom in granulosa cells, and P450c17 in theca cells. The results indicate that more controlled superovulatory responses may be achieved with a more precise control of gonadotrophin concentration.

The authors would like to thank Anthea Springbett and William Lamberson for assistance in the statistical analysis of the results, and John Baxter for help in the quantification of the in situ hybridization images. H. A. Garvrick received support from the University of Missouri and the Burroughs Welcome Fund. The work was partially supported by DEFRA.

\section{References}

Adams GP, Matteri PL, Kastelie JP, Ko JCH and Ginther OJ (1992) Association between surges of follicle stimulating hormone and the emergence of follicular waves in heifers Journal of Reproduction and Fertility 94 177-188

Armstrong DG and Webb R (1977) Ovarian follicular dominance: novel mechansims and protein factors Reviews of Reproduction 2 139-146

Armstrong DG, Baxter G, Gutierrez CG, Hogg CO, Glazyrin AL, Campbell BK, Bramley TA and Webb R (1998) Insulin-like growth factor binding protein -2 and -4 mRNA expression in bovine ovarian follicles: effect of gonadotrophins and developmental status Endocrinology 139 2146-2154

Armstrong DG, Gutierrez CG, Baxter G, Glazyrin AL, Mann GE, Woad KJ, Hogg CO and Webb R (2000) Expression of mRNA encoding IGF-I, IGFII and type 1 IGF receptor in bovine ovarian follicles Journal of Endocrinology 165 101-113

Bao B and Garverick HA (1998) Expression of steroidogenic enzyme and gonadotropin receptor genes in bovine follicles during ovarian follicular waves: a review Journal of Animal Science 76 1903-1921

Bao B, Garverick HA, Smith GW, Smith MF, Salfen BE and Youngquist RS (1997) Changes in messenger ribonucleic acid encoding luteinizing hormone receptor, cytochrome P450-side chain cleavage, and aromatase are associated with recruitment and selection of bovine ovarian follicles Biology of Reproduction 56 1158-1168

Campbell BK and Baird DT (2001) Inhibin A is a follicle stimulating hormone-responsive marker of granulosa cell differentiation, which has both autocrine and paracrine actions in sheep Journal of Endocrinology $169333-345$

Campbell BK, Telfer EE, Webb R and Baird DT (2000) Ovarian autografts in sheep as a model for studying folliculogenesis Molecular and Cellular Endocrinology 163 131-139

De la Sota RL, Lucy RL, Staples CR and Thatcher WW (1993) Effects of recombinant bovine somatotropin (Sometribove) on ovarian function in lactating and non lactating dairy cows Journal of Dairy Science $\mathbf{7 6}$ 1002-1013

Ginther OJ, Wiltbank MC, Fricke PM, Gibbons JR and Kot K (1996) Selection of the dominant follicle in cattle Biology of Reproduction $\mathbf{5 5}$ 1187-1194

Gong JG, Bramley TA and Webb R (1991) The effect of recombinant bovine somatotrophin on ovarian function in heifers: follicular populations and peripheral hormones Biology of Reproduction 45 941-949

Gong JG, Campbell BK, Bramley TA and Webb R (1996) Treatment with recombinant bovine somatotrophin enhances ovarian follicle development and increases the secretion of IGF-I by ovarian follicles in ewes Animal Reproduction Science 41 13-26

Gong JG, Baxter G, Bramley TA and Webb R (1997) Enhancement of ovarian follicle development in heifers by treatment with recombinant bovine somatotrophin: a dose-response study Journal of Reproduction and Fertility $11091-97$

Gutierrez CG, Ralph JH, Telfer EE, Wilmut I and Webb R (2000) Growth and antrum formation of bovine preantral follicles in long-term culture in vitro. Biology of Reproduction 62 1322-1328 
Hamilton SA, Xu ZZ, Kieborz KR, Youngquist RS and Garverick HA (1993) Relationship between ovarian follicular dynamics and follicle stimulating hormone levels during the bovine estrous cycle Journal of Animal Science 71 (Supplement 1) 212

Ireland JJ and Roche JF (1982) Development of antral follicles in cattle after prostaglandin-induced luteolysis: changes in serum hormones, steroids, follicular fluid, and gonadotrophin receptors Endocrinology 111 2077-2086

McNatty KP, Hudson N, Gibb M, Ball K, Henderson KM, Heath DA, Lun S and Kieboom LE (1985) FSH influences follicle viability, oestradiol biosynthesis and ovulation rate in Romney ewes Journal of Reproduction and Fertility 75 121-131

McNeilly AS, Picton HM, Campbell BK and Baird DT (1991) Gonadotropic control of follicle growth in the ewe Journal of Reproduction and Fertility Supplement 43 177-186

Price CA, Morris BA and Webb R (1987) Reproductive and endocrine effects of active immunization against a testosterone conjugate in heifers Journal of Reproduction and Fertility 81 149-160

SAS (1999) SAS System (Release 8.0) SAS Institute Inc., Cary, NC

Skyer DM, Garverick HA and Youngquist RS (1987) Populations and steroidogenesis in vitro of follicles from three different days of the bovine oestrous cycle Journal of Animal Science 64 1710-1716

Smyth CD, Miro F, Whitelaw PF, Howles CM and Hiller SG (1993) Ovarian thecal/interstitial androgen synthesis is enhanced by a folliclestimulating hormone-stimulated paracrine mechanism Endocrinology $1331532-1538$

Tian XC, Berndtson AK and Fortune JE (1995) Differentiation of bovine preovulatory follicles during the follicular phase is associated with increases in messenger ribonucleic acid for cytochrome P450 17 alpha-hydroxylase, but not P450 aromatase Endocrinology 136 5102-5110

Webb R and England BG (1982) Relationship between LH receptor concentrations in thecal and granulosa cells and in vivo and in vitro steroid secretion by ovine follicles during the preovulatory period Journal of Reproduction and Fertility 66 169-180

Webb R, Campbell BK, Garverick HA, Gong JG, Gutierrez CG and Armstrong DG (1999) Molecular mechanisms regulating follicular recruitment and selection Journal of Reproduction and Fertility Supplement 54 33-48

Xu ZZ, Garverick HA, Smith GW, Smith MF, Hamilton SA and Youngquist RS (1995a) Expression of messenger ribonucleic acid encoding cytochrome P450 side chain cleavage, cytochrome P450-17 $\alpha$ hydroxylase, and cytochrome $\mathrm{P} 450$ aromatase in bovine follicles during the first follicular wave Endocrinology 136 981-987

Xu ZZ, Garverick HA, Smith GW, Smith MF, Hamilton SA and Youngquist RS (1995b) Expression of follicle-stimulating hormone and luteinizing hormone receptor messenger ribonucleic acids in bovine follicles during the first follicular wave Biology of Reproduction 53 951-957

Youngquist RS, Garverick HA and Keisler DH (1995) Use of umbilical cord clamps in ovariectomies in cattle Journal of American Veterinary Medicine Association 207 474-475

Received 18 September 2001.

First decision 27 November 2001.

Revised manuscript received 15 January 2002.

Accepted 28 January 2002. 